Maria MICHUR-ZIEMBA

Uniwersytet Rzeszowski

\title{
Cele i zasady funkcjonowania Wspólnoty Niepodległych Państw
}

W $\begin{aligned} & \text { spólnota Niepodległych Państw powstała na mocy podpisanego po- } \\ & \text { rozumienia o utworzeniu WNP z } 8 \text { XII } 1991 \text { r. przez przywódców }\end{aligned}$ Rosji, Białorusi i Ukrainy ${ }^{1}$. Wolę przystąpienia do Wspólnoty zgłosiły 21 XII 1991 r. również inne republiki związkowe. W skład WNP nie weszły jedynie państwa bałtyckie. Powstanie Wspólnoty Niepodległych Państw wiązało się z procesem dezintegracji i rozkładu ZSRR, na który wpływ miało szereg czynników. Do czynników tych należy zaliczyć czynniki społeczne, polityczne, narodowościowe, religijne, kulturowe, gospodarcze, które spełniały funkcje swoistych katalizatorów, ukierunkowujących ten proces w poszczególnych republikach związkowych. Proces emancypacyjny był wieloetapowy, obejmujący najpierw walkę o uznanie własnego języka za urzędowy, postulat autonomii gospodarczej oraz politycznej, a następnie przyjęcie deklaracji suwerenności i niepodległości.

Decyzja o likwidacji ZSRR i utworzeniu WNP nie była decyzją konstytucyjna, została podjęta na fali negacji wszelkich struktur ogólnozwiązkowych. Określenie momentu rozpadu ZSRR i powstania WNP sprawia pewne trudności. Pierwsze porozumienie o likwidacji ZSRR i powstaniu WNP podjęły (8 XII 1991 r.) tylko trzy jego republiki związkowe. Powoływały się one przy tym na swój status republik założycielskich ZSRR. Nie wynikająjednak z tego powodu żadne implikacje w sferze prawa międzynarodowego. Rosja, Białoruś i Ukraina były jedynie trzema z dwunastu republik ZSRR, które - posiadając analogiczny status - decyzji takiej nie podjęły. Nie bez znaczenia był jednak fakt, że republiki, które podjęły decyzję o powstaniu WNP, wypowiadały się w imieniu $75 \%$ ludności, zamieszkującej $80 \%$ terytorium ZSRR, jak również to, że na ich terenie była rozmieszczona broń jądrowa ZSRR.

1 Zob. Издание Министерства Иностранных Дел Российской Федерации, „Дипломатический Вестник”, nr 1, Москва 1992, s. 3-6. 
Stanowiska wśród opinii międzynarodowej co do określenia momentu rozpadu ZSRR i powstania WNP były podzielone. Administracja prezydenta USA G. Busha wiązała moment rozpadu ZSRR i powstania na jego terytorium nowych państw z rezygnacją ze swojego stanowiska prezydenta ZSRR. Bezpośrednio po podpisaniu porozumienia białowieskiego (9 XII 1991) Stany Zjednoczone podtrzymały swoje uznanie dla ZSRR, następnie jednak Departament Stanu USA oświadczył o swojej gotowości zawierania umów ze Wspólnotą, jednocześnie utrzymując stosunki z ZSRR. Podczas wizyty sekretarza stanu USA G. Bakera w Moskwie (15 XII 1991), Rosja złożyła oficjalną prośbę o jej uznanie przez USA. Stany Zjednoczone uzależniły jednak spełnienie tej prośby, jak również następnej (poczynionej 23 XII 1991 r., już po złożeniu przez M. Gorbaczowa deklaracji, że ZSRR przestanie istnieć do końca roku), od zaprzestania działania przez urząd Prezydenta ZSRR. Dopiero 25 XII 1991 r., gdy M. Gorbaczow złożył swój urząd, Rosja, Ukraina, Białoruś, Armenia, Kazachstan i Kirgistan zostały uznane przez USA, Kanadę i Izrael. 27 XII 1991 r. Rosja i inne republiki związkowe zostały uznane przez $\mathrm{ChRL}^{2}$.

Prezydent Federacji Rosyjskiej B. Jelcyn jako datę rozpadu ZSRR i powstania WNP wskazał 8 XII $1991 \mathrm{r}^{3}$ Natomiast z komunikatu ministrów spraw zagranicznych państw NATO, zgromadzonych na sesji Rady NATO, która miała miejsce 19 XII 1991 r., wynika, że członkowie tej organizacji uważali wówczas, że ZSRR jeszcze istnieje. W swoim oświadczeniu stwierdzili oni, iż „będą okazywać pomoc Związkowi Radzieckiemu i jego republikom”4. Z kolei W. G. Miller uważa, że „Związek Radziecki formalnie przestał istnieć 21 grudnia, gdy w drodze porozumienia jedenastu z piętnastu republik ZSRR została utworzona Wspólnota Niepodległych Państw" ". Zdanie to jest podzielane również przez rosyjskiego naukowca W. Pustogarowa, który uważa, że celem spotkania w Ałma-Acie jedenastu państw byłego ZSRR było ponowne podpisanie

2 W. G. Miller, American Diplomacy and Soviet Desintegration, w: The Diplomatic Record 1991-1992, Boulder-San Francisco-Oxford 1993, s. 19.

3 Выступление Б. Н. Ельцина на лондонской фондовой бирже 10 ноября и совместная пресс-конференция Б. Н. Ельцина і Й. Анталла 11 ноября, „Дипломатический Вестник”, op. cit. 1992, nr 23-24, s. 13 і 33.

4 Komunikat z sesji Rady NATO, Bruksela, 19 grudnia 1991; ibidem 1992, nr 1, s. 45 .

5 W. G. Miller, American Diplomacy..., op. cit., s. 3. 
porozumienia o powstaniu WNP, a nie o jej rozszerzeniu, gdyż porozumienie z 8 XII 1991 r. było pozbawione skutków prawnych ${ }^{6}$.

Określenie momentu utworzenia państw powstałych w wyniku rozpadu ZSRR nie jest łatwe. Trafne jest więc stwierdzenie L. Antonowicza, że „kwestia daty powstania państwa jest nieraz trudna do rozstrzygnięcia [...]. Jest to [...] wynik dłużej lub krócej trwającego procesu, który nie da się sprowadzić do jakiegoś dnia"’7. Należy więc uznać, że rozpad ZSRR i powstanie WNP nie dokonało się w jednym momencie, był to proces trwający od 8 XII 1991 r. do 26 XII 1991 roku.

Intencje stron powołujących do życia WNP nie były jednakowe. Dla Rosji powołanie Wspólnoty było przede wszystkim sposobem przystosowania zespalających struktur wytworzonych przez ZSRR do nowych warunków, a zwłaszcza sposobem na utrzymanie instytucjonalnego związku Rosji z Ukrainą, która po ogłoszeniu niepodległości i przeprowadzeniu akceptującego ją referendum odmówiła kategorycznie podpisania jakiejkolwiek nowej umowy związkowej. Ponieważ Jelcyn uważał, że nowy związek bez Ukrainy nie jest możliwy, zdecydował się na luźniejszą formę więzi, ale zapewniającą udział w niej Ukrainy. Intencje prezydenta Ukrainy L. Krawczuka miały inny sens. Dla niego powołanie WNP miało być sposobem na cywilizowaną formę zlikwidowania wszelkich ponadpaństwowych instytucji i więzi Ukrainy, jakie pozostały po ZSRR. Intencje Białorusi, jako najsłabszej strony w tym układzie, były oparte na przekonaniu, iż utrzymanie każdego sposobu więzi między byłymi republikami radzieckimi leży w ich interesie ${ }^{8}$. Mimo różnych intencji stron, proces likwidacji ZSRR i powołanie Wspólnoty Niepodległych Państw został przeprowadzony w sposób pokojowy.

Podstawy prawne funkcjonowania WNP stanowią: akt założycielski WNP z 8 XII 1991 r., protokół do porozumienia o utworzeniu WNP, deklaracja Ałma-Acka z 21 XII 1991 r., podpisana przez pozostałe republiki związkowe (z wyjątkiem Gruzji) oraz Statut WNP.

W preambule porozumienia o utworzeniu WNP strony konstatują, że „Związek SRR - jako podmiot prawa międzynarodowego i rzeczywistość geopolityczna przestaje istnieć”. W tekście podstawowym stwierdzono również, że ,wraz z zawarciem niniejszego porozumienia na terytoriach

6 В. Пустогаров, Содружество в раккурсе международного права, „Международная Жизнь” 1992, nr 7-8, s. 16.

7 L. Antonowicz, Podręcznik prawa międzynarodowego, Warszawa 1994, s. 55.

8 Zob. dyskusję pt. Демонтаж, „Московские Новости”, z 22.12.1991, s. 8-9. 
państw, które go podpisały, nie dopuszcza się stosowania norm państw trzecich, w tym także byłego ZSRR” (art. 11) oraz iż: „działalność organów byłego ZSRR na terytoriach państw członkowskich Wspólnoty ustaje" (art. 14). W ramach Wspólnoty sygnatariusze postanowili rozwijać współpracę w zakresie polityki, gospodarki, kultury, oświaty, ochrony zdrowia, ochrony środowiska naturalnego, nauki, handlu, w sferze humanitarnej, a także prowadzić szeroką wymianę informacyjną. Uznali oni jednocześnie wzajemnie integralność terytorialną i nienaruszalność granic. Postanowili również zachować i utrzymać pod zjednoczonym dowództwem „wspólną przestrzeń wojskowo-strategiczną, włączając w to jednolitą kontrolę nad bronią jądrową”. Strony stwierdziły, że „w sferze ich wspólnej działalności, realizowanej na równoprawnej podstawie poprzez koordynacyjne organy Wspólnoty" znajdują się: koordynacja polityki zagranicznej, współpraca w formowaniu i rozwoju wspólnej przestrzeni gospodarczej, współpraca w rozwoju systemów transportu i łączności, ochrona środowiska naturalnego, udział w tworzeniu systemu bezpieczeństwa ekologicznego, zagadnienia polityki migracyjnej, a także walka ze zorganizowaną przestępczością.

Strony porozumienia zadeklarowały również, że ,gwarantują wypełnienie obowiązków międzynarodowych, wypływających dla nich z umów i porozumień byłego Związku SRR”. Sygnatariusze porozumienia oświadczyli, że porozumienie o utworzeniu WNP jest otwarte dla „wszystkich państw członkowskich byłego Związku SRR, a także dla innych państw, podzielających cele i zasady niniejszego Porozumienia".

Porozumienie o utworzeniu WNP zostało poddane procedurze ratyfikacyjnej. Parlamenty Białorusi i Ukrainy ratyfikowały je 10 XII 1991 roku, a 12 XII 1991 r. uczynił to parlament Federacji Rosyjskiej ${ }^{9}$.

Parlament Ukrainy w dokumencie ratyfikacyjnym zgłosił zastrzeżenia składające się z 12 punktów do omawianego porozumienia. Artykuł 5 porozumienia dotyczący otwarcia granic, swobodnego przemieszczania się obywateli i przekazywania informacji został zmodyfikowany w następujący sposób: państwa „gwarantują na wzajemnej podstawie otwartość istniejących między nimi granic dla ułatwienia kontaktów między ich obywatelami oraz przekazywania informacji w ramach WNP. W tym celu Strony w najbliższym czasie opracują odpowiednią podstawę prawną".

9 Jako ostatnie umowę ratyfikowały Azerbejdżan (24 IX 1993) i Gruzja (23 XII 1993). 
Porozumienie o utworzeniu WNP przewidywało również wspólną koordynację działalności państw w zakresie polityki zagranicznej (art. 7). Postanowienie to zostało zmienione na: „Strony będą prowadzić konsultacje w zakresie polityki zagranicznej". Zastrzeżenia zostały zgłoszone także do art. 6 o siłach zbrojnych WNP. Parlament Ukrainy uznał za stosowne zmienić dotychczasowe brzmienie tego artykułu na następujące: „Państwa członkowskie WNP reformując oddziały sił zbrojnych byłego ZSRR i tworząc na ich podstawie własne siły zbrojne, będą współpracować w zakresie zabezpieczenia międzynarodowego pokoju i bezpieczeństwa"10. Należy więc uznać, że porozumienie o utworzeniu WNP w stosunkach między Białorusią, Rosją i Ukrainą z prawnomiędzynarodowego punktu widzenia weszło w życie 12 XII 1991 roku.

Żadna z republik związkowych (z wyjątkiem przywódcy Kazachstanu Nursułtana Nazarbajewa), pominiętych w procesie podejmowania decyzji o likwidacji ZSRR i powołaniu WNP, nie wystapiła w obronie imperium. Nieprzygotowane jednak do samodzielnego funkcjonowania, zgłosiły one wolę przystapienia do Wspólnoty Niepodległych Państw, widząc w niej jedyną możliwą wówczas formę kontynuacji zespołowego istnienia. $\mathrm{Na}$ spotkaniu w Aszchabadzie 14 XII 1991 r. wolę przystąpienia do WNP wyraziły: Kazachstan, Kirgistan, Tadżykistan, Turkmenistan i Uzbekistan. Na początku grudnia 1991 r. prezydent Rosji poinformował, że „21 grudnia jeszcze sześć republik byłego Związku podpisze porozumienie o wstąpieniu do WNP, a do końca grudnia we Wspólnocie będzie już co najmniej 10 członków" "11.

Na spotkaniu w Ałma-Acie 21 XII 1991 r. protokół o przyłączeniu się do porozumienia o utworzeniu WNP z 8 XII 1991 r. podpisało jedenaście republik. Protokołu nie podpisała Gruzja, wstrząsana w tym czasie silnymi konfliktami wewnętrznymi, oraz Litwa, Łotwa i Estonia, które już wcześniej zerwały instytucjonalne więzy z innymi republikami, a ich niepodległość uznały władze ZSRR jeszcze we wrześniu 1991 r. Stronami protokołu zostały: Republika Azerbejdżańska, Republika Armenia, Republika Białoruś, Republika Kazachstan, Republika Kirgistan, Republika Mołdowa, Federacja Rosyjska, Republika Tadżykistan, Turkmenistan,

10 Por. „Известия” z 12.12.1991 r.

11 Sprawozdanie z konferencji prasowej prezydenta FR B. Jelcyna i sekretarza stanu USA G. Bakera, która miała miejsce 16 XII 1991 r. w Moskwie, zob.: „Дипломатический Вестник”, ор. cit., 1992, s. 24-25. 
Republika Uzbekistan i Ukraina ${ }^{12}$. Strony stwierdziły, że ,,porozumienie o utworzeniu Wspólnoty Niepodległych Państw nabiera mocy dla każdej z Wysokich Umawiających się Stron od momentu jego ratyfikacji”. W protokole została przewidziana możliwość zgłaszania zastrzeżeń, określona jako integralna część porozumienia o utworzeniu WNP. Tego samego dnia sygnatariusze protokołu podpisali również deklarację ałma-acką ${ }^{13}$. W deklaracji powtórzono zawarte w porozumieniu z 8 XII $1991 \mathrm{r}$. postanowienia, a mianowicie, że „,Z utworzeniem Wspólnoty Niepodległych Państw Związek SRR kończy swoje istnienie", oraz deklarowano uznanie przez strony integralności terytorialnej i nienaruszalności granic, zachowanie zjednoczonego dowództwa nad wojskowo-strategicznymi siłami zbrojnymi i jednolitej kontroli nad uzbrojeniem jądrowym, otwartość porozumienia o utworzeniu WNP dla przystapienia do niego wszystkich państw członkowskich byłego ZSRR, a także dla innych państw, podzielających cele i zasady Wspólnoty. W deklaracji postanowiono również, że „państwa członkowskie Wspólnoty gwarantują zgodnie ze swoimi konstytucyjnymi procedurami wypełnianie międzynarodowych obowiązków wynikających z umów i porozumień byłego ZSRR".

Porozumienie z 8 XII 1991 r. o utworzeniu WNP oraz protokół z 21 XII 1991 r. najpóźniej zostały ratyfikowane przez Azerbejdżan, Armenię i Mołdowę. Korzyści wynikające z rozpadu ZSRR dla tych państw były znacznie wyższe niż niedogodności związane ze znalezieniem się we Wspólnocie, gdyż w dokumentach białowieskich oraz ałmaackich stwierdzano koniec istnienia podmiotu mogącego mieć w stosunku do nich wówczas i w przyszłości roszczenia terytorialne. 21 XII 1991 r. w Ałma-Acie podpisano również porozumienia o koordynacji instytucji Wspólnoty Niepodległych Państw, o wspólnych środkach w odniesieniu do broni jądrowej oraz porozumienie o poparciu Rosji przez państwa WNP, aby kontynuowała członkostwo ZSRR w ONZ, łącznie ze stałym członkostwem w Radzie Bezpieczeństwa i innych organizacjach międzynarodowych $^{14}$.

Szereg postanowień porozumienia z 8 XII $1991 \mathrm{r}$. oraz protokołu z 21 XII 1991 r. zostały zmodyfikowane kolejnymi umowami zawieranymi

12 Tekst Protokołu do Porozumienia o utworzeniu Wspólnoty Niepodległych Państw podpisanego 8 grudnia 1991 roku w Mińsku przez Republikę Białoruś, Federację Rosyjską, Ukrainę w: ibidem, s. 6.

13 Tekst w: ibidem, s. 7.

14 Zob.: „Известия” z 23.12.1991 r. 
przez państwa członkowskie WNP. Umowy te ze względu na ich formę $i$ treść są typowymi umowami regulowanymi przez prawo międzynarodowe.

Zasadnicze znaczenie w zakresie dotyczącym struktury i zasad funkcjonowania Wspólnoty ma Statut WNP, uchwalony i podpisany 22 I $1993 \mathrm{r}$. przez państwa członkowskie Wspólnoty w Mińsku na posiedzeniu Rady Szefów Państw WNP ${ }^{15}$. Statut WNP składa się z 9 rozdziałów, zawierających 45 artykułów. Nie określono w nim jednak, jaki charakter prawnomiędzynarodowy posiada Wspólnota, stwierdzono jedynie, iż nie jest ona państwem i nie posiada ponadnarodowych pełnomocnictw. Za cele Wspólnoty uznano m.in.: realizację współpracy w różnych dziedzinach, stworzenie wspólnego obszaru gospodarczego, zapewnienie międzynarodowego bezpieczeństwa, dokonanie redukcji i likwidacji broni jądrowej, zagwarantowanie praw i wolności obywatelskich zgodnie z ogólnie przyjętymi zasadami i normami prawa międzynarodowego, a także dokumentami KBWE oraz zapewnienie ruchu bezwizowego dla obywateli państw członkowskich WNP, jak też pokojowe rozstrzyganie sporów pomiędzy tymi państwami (art. 2). Określono również zasady wzajemnych stosunków państw WNP (art. 3). Statut WNP nie określa kompetencji Wspólnoty, a jedynie formułuje zakres wspólnej działalności państw WNP, realizowany na podstawie równouprawnienia stron przez organy koordynacyjne zgodnie ze zobowiązaniami przyjętymi przez państwa członkowskie w ramach Wspólnoty. Do zadań tych należą: zabezpieczenie praw i podstawowych wolności człowieka, koordynacja polityki zagranicznej państw członkowskich, współpraca w formowaniu i rozwoju wspólnej przestrzeni gospodarczej, polityka celna, współpraca w rozwoju systemów transportu i łączności, ochrona zdrowia i środowiska naturalnego, sprawy z zakresu polityki społecznej i migracyjnej, walka ze zorganizowaną przestępczością oraz współpraca w zakresie polityki obronnej i ochrony granic zewnętrznych. W Statucie stwierdzono, iż zakres ten może być rozszerzony za zgodą państw członkowskich WNP. W praktyce takie działania są podejmowane na forum Rady Szefów Państw WNP i Rady Szefów Rządów WNP w zawieranych porozumieniach (art. 4). Podstawę prawną stosunków międzynarodowych państw członkowskich stanowią wielostronne i dwustronne porozumienia zawarte w ramach Wspólnoty,

15 Statut podpisały: Armenia, Białoruś, Kazachstan, Kirgistan, Rosja, Tadżykistan i Uzbekistan. Tekst Statutu WNP w: „Дипломатический Вестник”, op. cit., 1993, nr $9-10$, s. $31-38$. 
które powinny odpowiadać celom i zasadom WNP oraz zobowiązaniom zawartym w Statucie (art. 5).

Rozdział drugi Statutu jest poświęcony członkostwu we Wspólnocie. Członkostwo w WNP jest uzależnione od przyjęcia Statutu przez dane państwo oraz od zgody wszystkich państw członkowskich Wspólnoty. W związku z tym powstał problem określenia statusu państw, które Statutu nie przyjęły. Zgodnie z postanowieniami Statutu zostaną one państwami-założycielami WNP, ale nie będąjej członkami pełnoprawnymi. Mogą one korzystać z tzw. członkostwa stowarzyszonego, co pozwala im na uczestnictwo w niektórych dziedzinach działalności Wspólnoty (art. 8). Jednak koncepcja takiego członkostwa nie jest jasna, gdyż nie zostało określone, z kim państwo, posiadające taki status, może zawierać tego typu porozumienie. W Statucie jest przewidziana również możliwość wystąpienia ze Wspólnoty. Warunkiem wystąpienia jest wywiązanie się w pełnym zakresie ze zobowiązań powstałych w okresie, w którym strona była związana Statutem (art. 9). Projekt Statutu zakładał też możliwość wyłączenia ze Wspólnoty za systematyczne uchylanie się od wykonania zobowiązań. W ostatecznej wersji wyłączenie zostało jednak zastąpione możliwością zastosowania wobec takiego państwa kar przewidzianych przez prawo międzynarodowe (art. 10).

W części zawierającej postanowienia o współpracy wojskowo-politycznej i zbiorowym bezpieczeństwie podkreślono obowiązek prowadzenia wspólnej polityki w zakresie międzynarodowego bezpieczeństwa przez państwa członkowskie oraz powołania Sił Zbrojnych Wspólnoty (art. 11). W przypadku zaistnienia niebezpieczeństwa naruszenia suwerenności, bezpieczeństwa lub integralności terytorialnej państw Wspólnoty może być użyta siła w celu samoobrony indywidualnej lub zbiorowej, po wyczerpaniu środków pokojowych, zgodnie z art. 51 Karty NZ (art. 12). Statut zobowiązuje także państwa Wspólnoty do pokojowego rozstrzygania sporów i zapobiegania powstawaniu konfliktów na ich terytoriach (art. 16). Upoważniona do rozpatrywania sporów powstałych między państwami Wspólnoty jest Rada Szefów Państw WNP. Do jej kompetencji w tym zakresie należy jedynie zalecanie określonych metod i procedur (art. 18).

Statut WNP w rozdziale VI pt. „Organy Wspólnoty” przewiduje i reguluje funkcjonowanie: Rady Szefów Państw i Rady Szefów Rządów (art. 21-26), Rady Ministrów Spraw Zagranicznych WNP (art. 27), Komitetu Koordynacyjno-Konsultacyjnego WNP (art. 28-29), Rady Ministrów Obrony WNP i Naczelnego Dowództwa Zjednoczonych Sił Zbrojnych 
WNP (art. 30), Rady Dowódców Wojsk Ochrony Pogranicza WNP (art. 31), Sądu Gospodarczego WNP (art. 32) oraz Komisji Praw Człowieka WNP (art. 33). W artykule 34 Statutu WNP przewidziano ponadto możliwość dalszego działania i tworzenia „organów branżowych WNP”. Z kolei w rozdziale VII pt. „Współpraca Międzyparlamentarna” założono utworzenie Zgromadzenia Międzyparlamentarnego z siedzibą w Sankt-Petersburgu, składającego się z delegacji parlamentarnych państw członkowskich, którego prace są przygotowywane przez Radę Zgromadzenia. Tryb finansowania działalności WNP został określony w rozdziale VIII Statutu. Główne kompetencje w tym przedmiocie przyznano Radzie Szefów Państw i Radzie Szefów Rządów WNP (art. 39).

W postanowieniach końcowych Statutu przewidziano możliwość zgłaszania zastrzeżeń i wniosków do poszczególnych rozdziałów i artykułów (art. 43). Postanowienie to zostało włączone w celu umożliwienia przystapienia do Statutu państw, które wybiórczo uczestniczą w dziedzinach wspólnej działalności WNP. W art. 44 postanowiono, że Statut WNP podlega rejestracji zgodnie z art. 102 Karty NZ.

Jednym z podpisanych 21 XII 1991 r. w Ałma-Acie dokumentów było porozumienie o organach koordynacyjnych Wspólnoty Niepodległych Państw. Na jego mocy utworzono Radę Szefów Państw i Radę Szefów Rządów WNP dla „rozwiązywania problemów związanych z koordynacyjną działalnością państw Wspólnoty"16.

Do kompetencji Rady Szefów Państw, jako najwyższego organu WNP, należy rozwiązywanie problemów dotyczących wspólnej działalności państw WNP. Posiedzenia Rady są zwoływane dwa razy w roku lub też na wniosek jednego z państw członkowskich. Natomiast do kompetencji Rady Szefów Rządów należy koordynowanie działalności organów władzy wykonawczej państw członkowskich w sferze gospodarczej, socjalnej i innych. Rada Szefów Rządów jest zwoływana na posiedzenia cztery razy w roku. Organy te posiadaja jedynie kompetencje koordynacyjne. W ich skład wchodzą prezydenci i szefowie rządów, dlatego też stanowią one forum podejmowania decyzji międzypaństwowych.

Początkowo Rada Szefów Państw i Rada Szefów Rządów WNP były obsługiwane przez Grupę Roboczą do spraw Organizacyjno-Technicznego Przygotowania i Prowadzenia Posiedzeń tych organów z siedzibą

16 Porozumienie o organach koordynacyjnych Wspólnoty Niepodległych Państw z 21 XII 1991 r. Tekst w: „Дипломатический Вестник” op. cit., 1992, nr 1, s. 9. 
w Mińsku. Grupa Robocza wykonywała zadania zlecone jej przez obsługiwane przez nią organy, a jej pracami kierował koordynator. Państwa członkowskie WNP utrzymywały przy Grupie Roboczej swoje stałe przedstawicielstwa ${ }^{17}$. W wyniku przyjęcia Statutu WNP Grupa Robocza została przekształcona w organ główny WNP - Komitet Koordynacyjno-Konsultacyjny WNP (art. 28 i 29 Statutu WNP). Jest on organem wykonawczym i koordynacyjnym. W skład Komitetu wchodzi po dwóch przedstawicieli państw członkowskich oraz Koordynator Komitetu powoływany przez Radę Szefów Państw WNP. Jest on szefem Sekretariatu Komitetu i zastępcą przewodniczącego Komitetu. Do kompetencji Komitetu należy wypracowywanie i wnoszenie propozycji w sprawach współpracy w ramach WNP i rozwoju stosunków społeczno-gospodarczych, monitorowanie realizacji umów międzynarodowych w zakresie stosunków gospodarczych, organizowanie obrad przedstawicieli i ekspertów w celu przygotowywania projektów dokumentów przedkładanych na posiedzenia Rady Szefów Państw WNP i Rady Szefów Rządów WNP, zabezpieczanie przebiegu posiedzeń tych organów, a także udzielanie pomocy o charakterze organizacyjnym innym organom WNP. Przygotowanie posiedzeń Rady Szefów Państw i Rady Szefów Rządów WNP należy do Rady Ministrów Spraw Zagranicznych WNP. Zgodnie z art. 27 Statutu WNP, który określając kompetencje tego organu stwierdza, że „Rada Ministrów Spraw Zagranicznych na podstawie decyzji Rady Szefów Państw i Rady Szefów Rządów WNP koordynuje politykę zagraniczną państw członkowskich, jak również działalność w organizacjach międzynarodowych oraz organizuje konsultacje w sprawach objętych wzajemnym interesem stron".

W ramach Wspólnoty przewidziana jest również współpraca międzyparlamentarna. W tym celu zostało utworzone Zgromadzenie Międzyparlamentarne z siedzibą w Sankt-Petersburgu. W jego skład wchodzą delegacje parlamentarne państw członkowskich. Zgodnie z art. 36 Statutu WNP: „Zgromadzenie Międzyparlamentarne przeprowadza międzyparlamentarne konsultacje, omawia kwestie współpracy w ramach Wspólnoty, wypracowuje wspólne wnioski w zakresie działalności parlamentów narodowych”.

17 Rada Szefów Państw WNP podjęła 6 VII 1992 r. w Moskwie decyzję o budowie siedziby organów koordynacyjnych Wspólnoty i przedstawicielstw państw członkowskich Wspólnoty w Mińsku. Tekst w: „Содружество, Информационный Вестник Совета Глав Государств и Совета Глав Правительств СНГ”, выпуск шестой, Минск 1992, s. 72. 
Organizację pracy tego organu zapewnia składająca się z przewodniczących delegacji Rada Zgromadzenia. Posiedzenia Zgromadzenia Międzyparlamentarnego są zwoływane dwa razy w roku. Decyzje uchwalane przez Zgromadzenie mają charakter zaleceń.

Zasadą przy podejmowaniu decyzji przez organy WNP jest consensus. W praktyce jednak organy Wspólnoty stosują zasadę, znaną z RWPG pod nazwą: „consensus minus jeden”. Potwierdza to podpisane już 30 XII 1991 r. tymczasowe porozumienie o Radzie Szefów Państw i Radzie Szefów Rządów WNP, w którym przewidziano prawo każdego z zasiadających w nich państw do nieuczestniczenia w przyjętym porozumieniu, o ile dane państwo oświadczy o swoim niezainteresowaniu w tym przedmiocie. Również porozumienie o tymczasowych zasadach procedury Rady Szefów Państw i Rady Szefów Rządów WNP, przyjęte 15 V 1992 r. w Taszkiencie, zawiera stwierdzenie, że każde państwo ma prawo „oświadczyć o swoim niezainteresowaniu tą lub inną sprawą, co nie jest przeszkodą dla podjęcia decyzji”18. Zasada „consensus minus jeden” została także powtórzona w art. 23 Statutu WNP. Rada Szefów Państw i Rada Szefów Rządów WNP, podejmując decyzje w kwestiach proceduralnych, decydują większością głosów.

Zasada „consensus minus jeden” jest widoczna na przykładzie decyzji, podejmowanych przez Radę Szefów Państw i Rady Szefów Rządów WNP ${ }^{19}$.

18 Art. 12 porozumienia o tymczasowych zasadach procedury Rady Szefów Państw i Rady Szefów Rządów państw członkowskich Wspólnoty Niepodległych Państw. Tekst w: „Содружество..., op. cit.” 1992, выпуск пятый, s. 40-44.

19 Z zawartych porozumień, przewidujących utworzenie organów koordynacyjnych, jednogłośnie zostało przyjęte tylko porozumienie o utworzeniu Rady do spraw Transportu Kolejowego WNP. W pierwszym półroczu istnienia WNP państwa Wspólnoty podpisały 88 porozumienia o charakterze gospodarczym i wojskowo-politycznym, jednak tylko Rosja i Kazachstan związały się wszystkimi, natomiast Ukraina podpisała 34, Turkmenistan - 36. Porozumienie o utworzeniu i statusie Sądu Gospodarczego WNP z 6 VII 1992 r. podpisało tylko 8 państw, w tym jedno z zastrzeżeniem. Porozumienie o utworzeniu Rady Celnej WNP podpisało 9 państw, w tym cztery z zastrzeżeniem. Natomiast porozumienie o informacyjnym zabezpieczeniu systemu zarządzania i ochrony informacji tajnych Zjednoczonych Sił Zbrojnych WNP i Sił Zbrojnych państw członkowskich podpisało tylko 5 państw członkowskich WNP. Wykaz porozumień zawartych w ramach WNP wraz z wykazem państw, które je podpisały, w: В. Амелькина, К. Боришполец, М. Хрусталеб, В. Егоров, Т. Рузинская, А. Загорский, А. Злобин, Содружество Независимых Государств: Проиессы и Перспективы, Доклад Центра Международных Исследований МГИМО, Москва 1992, s. 26-36. 
Statut WNP w art. 34 przewiduje możliwość tworzenia „organów branżowych", które również są organami koordynacyjnymi ${ }^{20}$. Wśród powołanych organów koordynacyjnych znalazły się m.in.: Rada Zbiorowego Bezpieczeństwa, Międzypaństwowa Rada Ekologiczna WNP, Międzypaństwowa Rada ds. Hydrometeorologii WNP, Rada Elektroenergetyczna WNP, Rada Celna WNP, Międzypaństwowa Rada WNP ds. Przestrzeni Kosmicznej, Międzypaństwowy Komitet Lotniczy WNP, Komitet Strategiczny WNP, Rada ds. Transportu Kolejowego WNP, Międzypaństwowa Rada WNP ds. Nadzoru nad Obsługą Długu i Wykorzystania Aktywów ZSRR, Międzypaństwowa Rada WNP ds. Standaryzacji, Miernictwa i Certyfikacji, Międzypaństwowa Komisja WNP ds. Importu Towarów Spożywczych, Międzypaństwowa Rada Naukowo-Techniczna WNP ds. Współpracy w zakresie Ochrony Zdrowia, Międzypaństwowe Stowarzyszenie Teleradiofoniczne WNP, Rada Ministrów Spraw Wewnętrznych państw członkowskich WNP, Konsultacyjno-Koordynująca Rada Gospodarcza WNP, Zjednoczone Dowództwo Wojsk Ochrony Pogranicza WNP, Międzypaństwowy Bank WNP oraz Sąd Gospodarczy. Wśród organów koordynacyjnych WNP można wyróżnić organy o charakterze stałym i czasowym. Przykładowo Statut Międzypaństwowej Rady WNP ds. Nadzoru nad Obsługą Długu i Wykorzystaniem Aktywów Związku SRR określa, że „Międzypaństwowa Rada kończy swoją działalność po wykonaniu postanowień umowy"21. Porozumienie o utworzeniu Międzypaństwowej Rady Naukowo-Technicznej WNP z 13 III 1992 r. było zawarte na okres pięcioletni $^{22}$. Natomiast porozumienie o międzypaństwowej wymianie informacji naukowo-technicznej z 26 VI 1992 r., przewidujące utworzenie

$20 \mathrm{~Np}$. typowym organem branżowym WNP powołanym w celu rozwoju współpracy państw członkowskich w dziedzinie kultury i sztuki jest Rada ds. współpracy w dziedzinie kultury i sztuki. Rada ta została powołana na podstawie decyzji Rady Szefów Państw z 26 V 1995 r. W skład Rady wchodzą wytypowani wybitni przedstawicie kultury i sztuki państw WNP, a także przewodniczący koordynacyjnej rady międzynarodowych stowarzyszeń kultury i sztuki państw WNP. Rada opracowuje program wspólnych imprez kulturalnych na terytorium Wspólnoty.

21 Art. 6 Statutu Międzypaństwowej Rady ds. Nadzoru nad Obsługą Długu i Wykorzystaniem Aktywów ZSRR (podpisany na posiedzeniu Rady Szefów Rządów WNP, Moskwa 13 III 1992). Nie przystąpiły do niego Turkmenistan i Uzbekistan. Tekst w: „Содружество..., op. cit.” 1992, выпуск третий, s. 23.

22 Art. 18 w zw. z art. 3 porozumienia o współpracy naukowo-technicznej między państwami członkowskimi Wspólnoty Niepodległych Państw (podpisane na posiedzeniu Rady Szefów Rządów WNP, Moskwa 13 III 1992). Porozumienie to nie zostało podpisane przez Turkmenistan. Tekst w: ibidem, s. 29-33. 
Międzypaństwowej Koordynacyjnej Rady WNP ds. Informacji Naukowo-Technicznych zostało zawarte na czas nieokreślony ${ }^{23}$.

Jednym z typowych organów koordynacyjnych WNP jest Rada Ministrów Spraw Wewnętrznych państw członkowskich WNP. Rada Szefów Państw WNP 10 I 1996 r. podjęła decyzję o utworzeniu tego organu celem współpracy i koordynacji działań w zakresie przeciwdziałania przestępczości ${ }^{24}$. Jej członkami są ministrowie spraw wewnętrznych państw członkowskich Wspólnoty. W posiedzeniach Rady mogą ministrów zastępować wiceministrowie. Decyzje Rady mają charakter zaleceń. Do zadań podstawowych Rady należą m.in.: współpraca w zwalczaniu przestępczości, realizacja postanowień Rady Szefów Państw i Rady Szefów Rządów WNP w przedmiocie należącym do kompetencji Rady Ministrów Spraw Wewnętrznych, nadzorowanie przestrzegania porządku prawnego w innych dziedzinach działalności ministerstw spraw wewnętrznych. Kompetencje Rady obejmują między innymi: rozpatrywanie zagadnień dotyczących zwalczania przestępczości, organizowanie współpracy ministerstw spraw wewnętrznych państw członkowskich WNP, przygotowanie porozumień w przedmiocie współpracy państw WNP w zakresie zwalczania przestępczości, jak też współdziałanie w wymianie wzajemnych informacji i doświadczeń między ministerstwami spraw wewnętrznych państw WNP. Rada może powoływać organy, zajmujące się określonymi problemami ${ }^{25}$.

Specyficznym organem koordynacyjnym WNP jest natomiast Rada Celna. Powołano ją na podstawie porozumienia o zasadach polityki celnej z 13 III 1992 r. $^{26}$ Porozumienie to stwierdza, że ,państwa-strony, chcąc za-

23 Porozumienie o międzypaństwowej wymianie informacji naukowo-technicznych (podpisane na posiedzeniu Rady Szefów Rządów WNP, Mińsk, 26 VI 1992). Porozumienie to nie zostało podpisane przez Turkmenistan. Tekst w: ibidem, 1992, выпуск шестой, s. 32-35.

24 Postanowienie Rady Szefów Państw o utworzeniu Rady Ministrów Spraw Wewnętrznych celem współpracy i koordynacji działań w zwalczaniu przestępczości (podpisane na posiedzeniu Rady Szefów Państw, Moskwa 10 I 1992). Tekst w: „Дипломатический Вестник”, op. cit., 1996, nr 7, s. 41.

25 Przykładowo, zostało przez nią powołane Biuro ds. koordynacji walki z przestępczością zorganizowaną na terytoriach państw Wspólnoty. Dyrektora Biura i jego zastępcę powołuje i odwołuje Rada na okres 2 lat. Obsługę techniczną Rady zapewnia Sekretariat. Siedzibą Sekretariatu jest Mińsk. Koszty działania Sekretariatu Rady współfinansują państwa członkowskie.

26 Porozumienie o zasadach polityki celnej, wraz ze stanowiącym jego integralną część regulaminem Rady Celnej (podpisane na posiedzeniu Rady Szefów Państw WNP, Moskwa 13 III 1992). Zastrzeżenie do tych dokumentów zgłosiła Armenia oraz 
chować i umocnić jednolitą przestrzeń gospodarczą w ramach WNP oraz dążąc do zabezpieczenia $w$ granicach tej przestrzeni swobodnego przepływu towarów”, postanowiły „utworzyć Związek Celny, będący w zakresie swoich funkcji samodzielnym podmiotem prawa międzynarodowego". Sprzeciw w tej kwestii zgłosiła Mołdowa, która stwierdziła, że wszystkie problemy należy rozwiązywać poprzez porozumienia dwustronne. Z kolei rosyjska doktryna prawa międzynarodowego uznaje Radę Celną za organ koordynacyjny $\mathrm{WNP}^{27}$.

Organy koordynacyjne WNP mają zróżnicowany zakres kompetencji. Takie organy, jak Rada Szefów Państw WNP, Rada Szefów Rządów WNP oraz Rada Ministrów Spraw Zagranicznych WNP, w skład których wchodzą przedstawiciele państw, upoważnieni do reprezentowania swoich państw w obrocie prawnomiędzynarodowym, posiadają kompetencje do zaciagania zobowiązań w imieniu państw członkowskich. Na posiedzeniach tych organów są zawierane umowy międzynarodowe. Zazwyczaj porozumienia są zawierane w trybie prostym, rzadziej natomiast ich wejście w życie jest uzależnione od ich ratyfikacji. Czasami jest stosowana również tzw. klauzula o zróżnicowanym przyjęciu. W porozumieniach takich stwierdza się, że ,wchodzi ono w życie od dnia podpisania, a dla państw-stron, których ustawodawstwa wymagają ratyfikacji takich porozumień, od dnia złożenia przez nie państwu-depozytariuszowi dokumentów ratyfikacyjnych" 28 .

Jednym z głównych organów koordynacyjnych jest Sąd Gospodarczy WNP, który został utworzony na podstawie porozumienia o środkach za-

Mołdowa. Regulaminu Rady Celnej nie podpisała Ukraina. Tekst w: „Содружество... op. cit." 1992, выпуск третий, s. 8-14.

27 В. Амелькина, К. Боришполец, М. Хрусталеб, В. Егоров, Т. Рузинская, A. Загорский, А. Злобин, ор. cit., s. 7 i 28.

28 Np. art. 4 porozumienia o statusie Sądu Gospodarczego Wspólnoty Niepodległych Państw, podpisanego 6 VII 1992 r. na posiedzeniu Rady Szefów Państw WNP. Tekst w: „Содружество... op. cit.” 1992, выпуск шестой, s. 54. Porozumienia o utworzeniu organów koordynacyjnych WNP nie były podpisywane przez wszystkie państwa WNP. Przykładowo, według stanu na dzień tworzenia tych organów Ukraina nie podpisała jedenastu z nich, Białoruś dwóch, Turkmenistan pięciu, a Kirgistan i Uzbekistan nie podpisały po jednym porozumieniu. Niektóre z powołanych organów koordynacyjnych funkcjonują jedynie na papierze, gdyż państwa, nie dostrzegając potrzeby ich funkcjonowania, rozwiązują kwestie należące do ich kompetencji w drodze zawierania dwustronnych porozumień. Natomiast w zakresie, w którym niezbędne jest współdziałanie wszystkich państw Wspólnoty (np. transportu, elektroenergetyki itp.), państwa członkowskie odwołują się do organów koordynacyjnych. 
bezpieczenia polepszenia rozliczeń między organizacjami gospodarczymi państw członkowskich WNP z 15 V 1992 r. ${ }^{29}$ Na posiedzeniu Rady Szefów Państw WNP 6 VII 1992 r. zostało podpisane porozumienie o jego statusie $^{30}$. Funkcjonowanie Sądu Gospodarczego przewiduje również art. 32 Statutu WNP. Swoją działalność Sąd Gospodarczy rozpoczął w 1994 roku.

Sąd Gospodarczy WNP został utworzony „w celu zabezpieczenia jednolitego stosowania porozumień państw członkowskich Wspólnoty Niepodległych Państw oraz opartych na nich obowiązków gospodarczych i umów w drodze rozwiązywania sporów, wynikających ze stosunków gospodarczych”, a także dla „przywrócenia zerwanych związków gospodarczych między przedsiębiorstwami państw WNP”31. Zgodnie z art. 35 Statutu WNP językiem oficjalnym Sądu jest, ,język międzypaństwowych kontaktów, przyjęty we Wspólnocie”, tj. język rosyjski. Siedzibą Sądu jest Mińsk.

Regulamin Sądu Gospodarczego określa jego kompetencje oraz procedurę rozwiązywania sporów. Do kompetencji Sądu należy rozstrzyganie sporów gospodarczych wynikających z wykonania zawartych porozumień, decyzji Rady Szefów Państw, Rady Szefów Rządów WNP i innych instytucji oraz dotyczących zgodności aktów normatywnych przyjętych przez organy państw członkowskich z zawartymi przez państwa porozumieniami. Państwa członkowskie w drodze porozumienia mogą przekazać do rozpatrzenia również inne spory, związane $\mathrm{z}$ wykonywaniem porozumień i przyjętych na ich podstawie innych aktów Wspólnoty $(\text { pkt. 3) })^{32}$. Sprawy są rozpatrywane przez Sąd Gospodarczy na wniosek zainteresowanych państw lub instytucji $\mathrm{WNP}^{33}$.

29 Art. 5 porozumienia o środkach zabezpieczenia polepszenia rozliczeń między organizacjami gospodarczymi państw członkowskich WNP (podpisanego na posiedzeniu Rady Szefów Państw WNP, Taszkient, 15 V 1992). Zastrzeżenie o wykreśleniu tego artykułu złożyły: Azerbejdżan, Mołdowa i Ukraina. Nie podpisały porozumienia Kirgistan i Turkmenistan. Tekst w: „Содружество... op. cit.” 1992, выпуск пятый, s. 12.

30 Porozumienie o statusie Sądu Gospodarczego WNP wraz ze stanowiącym jego integralną część regulaminem Sądu Gospodarczego WNP (podpisane na posiedzeniu Rady Szefów Państw WNP, Moskwa, 6 VII 1992). Porozumienia tego nie podpisały Azerbejdżan, Turkmenistan, Ukraina. Tekst w: ibidem, 1992, выпуск шестой, s. 53-57.

31 Pkt 1 regulaminu Sądu Gospodarczego WNP, będącego załącznikiem do porozumienia z 6 VII 1992 r.

32 Заседание Совета Глав Государств - участников СНГ, zob. w: „Дипломатический Вестник, op. cit.” 1992, nr 15-16, s. 31.

33 Zastrzeżenie do tego przepisu zgłosiła Mołdowa. W odniesieniu do niej przepis ten w całości został wykreślony, a podstawą przekazania Sądowi danej sprawy do rozstrzygnięcia jest zgoda wszystkich państw będących stronami sporu. 
Sąd składa się z równej liczby sędziów z każdego państwa członkowskiego (po dwóch z każdego państwa), którzy są wybierani na okres 10 lat zgodnie z zasadami przewidzianymi dla wyboru sędziów w poszczególnych państwach członkowskich. Sędziowie są niezawiśli, nie podlegają jurysdykcji państw, na terenie których przebywaja.

Sąd Gospodarczy wydaje decyzje o charakterze zaleceń. W orzeczeniu takim Sąd wskazuje na naruszenie (lub nie) przez państwo członkowskie porozumienia, decyzji Rady Szefów Państw WNP, Rady Szefów Rządów WNP lub aktów podjętych przez inne instytucje WNP oraz zaleca środki, jakie powinny być podjęte. Sąd Gospodarczy posiada osobowość prawną, jego orzeczenia oraz postanowienia jego Plenum podlegają obligatoryjnej publikacji w wydawnictwach oficjalnych WNP.

Od momentu powołania do życia Wspólnoty jej członkowie za jeden z ważniejszych celów uznali dążenie do zachowania wspólnej przestrzeni wojskowej oraz wspólnego dowództwa. Podkreślono to już w grudniu podczas spotkania przywódców Rosji, Ukrainy i Białorusi, a następnie 21 grudnia 1991 r. Podpisano wówczas porozumienie o utworzeniu Zjednoczonych Sił Zbrojnych WNP ${ }^{34}$. Na posiedzeniu Rady Szefów Państw WNP 6 VII 1992 r. podpisano porozumienie o organizacji działalności Naczelnego Dowództwa Zjednoczonych Sił Zbrojnych Wspólnoty Niepodległych Państw ${ }^{35}$. Kwestia tworzenia wspólnego bezpieczeństwa zbiorowego została podjęta w podpisanym 15.05.92 r. Układzie o Bezpieczeństwie Zbiorowym tzw. Traktacie Taszkienckim ${ }^{36}$. Przewidywał on między innymi wspólne konsultacje oraz wspólne działania w sytuacji zagrożenia bezpieczeństwa, integralności terytorialnej, suwerenności któregokolwiek z państw - stron Układu. Koordynatorem współpracy stron Traktatu miała być powołana Rada Bezpieczeństwa Zbiorowego (art. 3).

34 Na czele Dowództwa ZSZ WNP stanął dotychczasowy minister obrony ZSRR, marszałek lotnictwa J. Szaposznikow. Dowództwu temu podporządkowano strategiczne siły jądrowe, a decyzję o ich użyciu mogły podejmować Rosja, Ukraina, Białoruś i Kazachstan po konsultacji z innymi państwami członkowskimi Wspólnoty. Naczelne Dowództwo ZSZ WNP podlegało Radzie Szefów Państw Wspólnoty.

35 Porozumienie o organizacji działalności Naczelnego Dowództwa Zjednoczonych Sił Zbrojnych Wspólnoty Niepodległych Państw w okresie przejściowym (podpisane na posiedzeniu Rady Szefów Państw WNP, Moskwa, 6 VII 1992). Tekst w: „Содружество... ор. cit.” 1992, выпуск шестой, s. 69-70.

${ }^{36}$ Umowę o zbiorowym bezpieczeństwie podpisały: Armenia, Kazachstan, Kirgistan, Federacja Rosyjska, Tadżykistan i Uzbekistan. Nie została ona jednak ratyfikowana przez Federację Rosyjską. Tekst w: ibidem, 1992, выпуск пятый, s. 9-11. 
W umowie tej postanowiono też, że agresja wymierzona w jedno z państw członkowskich stanowi casus belli dla wszystkich członków układu $(\text { art. } 4)^{37}$. W skład Rady Zbiorowego Bezpieczeństwa wchodzą szefowie państw członkowskich WNP oraz Naczelny Dowódca Zjednoczonych Sił Zbrojnych WNP. Siedzibą tego organu koordynacyjnego jest Moskwa ${ }^{38}$.

Realizacja Układu o Bezpieczeństwie Zbiorowym napotkała wiele trudności. Zasadniczy spór w WNP, dotyczący budowy systemu bezpieczeństwa zbiorowego, toczył się pomiędzy Rosją a Ukrainą, Kazachstanem i Mołdową. Te trzy państwa zmierzały do stworzenia systemu bezpieczeństwa zbiorowego, w którym byłyby równoprawnymi partnerami. Z kolei Rosja dążyła do utworzenia na obszarze Wspólnoty struktury wojskowej, w której odgrywałaby decydującą rolę. Powstanie narodowych armii w państwach WNP, łącznie z brakiem silnych struktur wspólnotowych, spowodowało duże trudności w działaniu Zjednoczonego Dowództwa. W rezultacie 15 czerwca 1993 roku na wniosek FR zostało rozwiązane. W jego miejsce został utworzony Zjednoczony Sztab ds. Koordynacji Współpracy Państw WNP, z gen. W. Samsonowem na czele. Jak słusznie zauważył M. Całka, „W rzeczywistości zlikwidowano jedynie fikcję współpracy wojskowej WNP. Jedynym państwem posiadającym rzeczywiste, narodowe, lojalne i zdolne do działań w każdym punkcie Wspólnoty siły zbrojne pozostawała Rosja. Ona też zachowała pełnię kontroli operacyjnej nad strategicznymi środkami bojowymi byłego ZSRR"39.

W ramach Wspólnoty Niepodległych Państw były powołane także Wojska Ochrony Pogranicza. Podstawą funkcjonowania tych wojsk było porozumienie o Siłach Zbrojnych i Wojskach Ochrony Pogranicza z 30 XII 1991 r. oraz porozumienie o statusie Wojsk Ochrony Pogranicza $\mathrm{WNP}^{40}$. W maju $1992 \mathrm{r}$ zawarto porozumienie, w którym określono zasa-

37 Na temat Traktatu Taszkienckiego zob. np.: M. Całka, A. Kupich, Wspólnota Niepodległych Państw, w: Europejskie struktury współpracy. Informator, red. S. Parzymies, Warszawa 1995, s. 122-123; R. Zięba, Mechanizm bezpieczeństwa WNP, „Polityka Wschodnia” 1998, nr 1, s. 63.

38 Porozumienie o zatwierdzeniu regulaminu o Radzie Zbiorowego Bezpieczeństwa, wraz ze stanowiącym jego integralną część regulaminem Rady Kolektywnego Bezpieczeństwa (podpisane na posiedzeniu Rady Szefów Państw WNP, Moskwa, 6 VII 1992). Tekst w: „Содружество... op. cit.” 1992, выпуск пятый, s. 61-63.

39 Ibidem, s. 125.

40 Porozumienia te zostały podpisane na posiedzeniu Rady Szefów Państw WNP 20 III 1992 r. w Kijowie. Teksty w: ibidem, 1992, выпуск четвертый, s. 36-39, 31-33, 34-36. 
dy kompletowania Wojsk Ochrony Pogranicza WNP i odbywania w nich służby wojskowej ${ }^{41}$. Na posiedzeniu Rady Szefów Państw WNP w Moskwie 6 lipca 1992 r. podjęto decyzję o utworzeniu Rady Dowódców Wojsk Ochrony Pogranicza WNP, w miejsce dotychczasowego jednolitego dowództwa ${ }^{42}$. Rada ta, jako organ koordynujący, otrzymała umocowanie $\mathrm{w}$ art. 31 Statutu WNP.

Podstawowe zasady współpracy służb wywiadowczych i organów bezpieczeństwa państw WNP określono w porozumieniu z 16 VI 1992 r. Rosja przejęła całą cywilną służbę wywiadowczą ZSRR, dlatego też zobowiązała się w tym porozumieniu, że nie będzie prowadzić działalności agenturalnej na terenie $\mathrm{WNP}^{43}$.

Zasadniczym elementem określającym koncepcję bezpieczeństwa WNP jest zinstytucjonalizowany mechanizm konsultacyjny przywódców państw członkowskich. Należy jednak zauważyć, że podejmowane w ramach Wspólnoty porozumienia w sferze wojskowej są nieraz dość ogólnikowe. Wynika to $\mathrm{z}$ tego, że znaczna część państw członkowskich Wspólnoty jest niechętna tworzeniu integracji, która w rzeczywistości byłaby zdominowana przez jedno państwo - Rosję.

Rosja w państwie radzieckim zajmowała zawsze szczególną pozycję. Jak słusznie zauważył D. K. Sims, „stanowiła ona jądro imperium”44. O kluczowej roli Rosji decydował przede wszystkim jej potencjał demograficzny i militarny. W stosunkach międzynarodowych Rosja była postrzegana jako zasadnicza część ZSRR i nieraz była z nim utożsamiana. Dlatego też RSFRR nie występowała obok ZSRR w zawieranych przez niego aktach prawnomiędzynarodowych, jak na przykład czyniła to Ukraina i Białoruś.

Szczególna pozycja Rosji uwidoczniła się również w procesie rozpadu ZSRR. Przyjęła ona w 1990 roku (14 czerwca), tak jak i inne republiki związkowe, deklarację suwerenności państwowej, jednak w odróżnieniu od innych nie przyjęła deklaracji niepodległości. De facto Rosja usamodzielniła się, przyjmując pod swoją kontrolę wszystkie siłowe resorty centralne.

41 Porozumienie to podpisano na posiedzeniu Rady Szefów Państw WNP 15 V 1992 r. w Taszkiencie. Nie zostało ono podpisane przez Azerbejdżan, Mołdowę i Ukrainę. Tekst w: ibidem, 1992, выпуск пятый, s. 17-19.

42 Decyzja o utworzeniu Rady Dowódców Wojsk Ochrony Pogranicza. Tekst w: ibidem, 1992, выпуск шестой, s. 71.

43 A. Grajewski, Przebudowa rosyjskich służb specjalnych, cz. I, „Biuletyn Ośrodka Studiów Wschodnich" 1992, nr 14, s. 33-34.

44 Д. К. Симс, Умом Россию не понять, „Летиратурная Газета” z 5.08.1992 r. 
Po rozpadzie ZSRR opinia społeczności międzynarodowej co do kwestii, czy Rosja jest jego sukcesorem, czy kontynuatorem, nie była jednakowa. Wiele państw uważało, że akty uznania Rosji są niepotrzebne ze względu na fakt, że Federacja Rosyjska jest sukcesorem $Z_{S R R}{ }^{45}$. W przekazanym 24 XII 1991 r. oświadczeniu premiera Wielkiej Brytanii J. Majora do prezydenta RSFRS B. Jelcyna stwierdzono, że Wielka Brytania uznaje „sukcesję przez Rosję międzynarodowych praw i obowiązków byłego ZSRR, włączając w to także te, które wynikają z Karty NZ". Natomiast ambasador RFN w Moskwie K. Bloch na spotkaniu z ministrem spraw zagranicznych Rosji A. Kozyriewem 25 XII 1991 r. stwierdził, że „Federacja Rosyjska jest kontynuatorem ZSRR i w związku z tym nie istnieje potrzeba formalnego aktu dyplomatycznego uznania"46.

O tym, że Rosja jest kontynuatorem prawnomiędzynarodowym ZSRR świadczą następujące fakty. Państwa członkowskie Wspólnoty Niepodległych Państw 21 XII 1991 r. podjęły uchwałę, w której poparły stanowisko, aby Rosja kontynuowała stan członkostwa ZSRR w ONZ wraz ze stałym członkostwem w Radzie Bezpieczeństwa, a także w innych organizacjach międzynarodowych ${ }^{47}$. Wyrażenie zgody przez ONZ oraz inne organizacje międzynarodowe na kontynuowanie członkostwa ZSRR przez Rosję oznacza przyjęcie przez nie koncepcji tożsamości prawnomiędzynarodowej ZSRR.

Rosja przejęła całą sieć dyplomatyczną byłego ZSRR, a także zachowała status mocarstwa strategicznego. Ambasady radzieckie za granicą przekształciły się w ambasady rosyjskie, natomiast ambasady państw obcych w Moskwie stały się ambasadami w Federacji Rosyjskiej ${ }^{48}$.

W Karcie NZ Rosja jest wymieniona kilkakrotnie pod dawną nazwa, nie stanowi to jednak przeszkody w uznaniu ją za kontynuatora ZSRR. Jak słusznie zauważył W. Pustogarow, ,zmiana nazwy państwa nie ma żadnego wpływu na jego tożsamość prawnomiędzynarodową"49.

45 Zob.: „Дипломатический Вестник”, op. cit., 1992, nr 1, s. 36.

46 Ibidem, s. 33.

47 Commonwealth of Independent States Documents adopted by the Heads of State and Government, December 1991-30 April 1992, Foreign Broadcast Information Service, Special Memorandum, may 1992, s. 8.

48 Zob.: „Московские Новости” z 10.05.1992 r.

49 В. Пустогаров, Эрозия Союза. Международно-правовые последствия, „Международная Жизнь” 1991, nr 11, s. 74-82. 
Rosja jako kontynuator prawnomiędzynarodowy ZSRR jest podmiotem praw i obowiązków nabytych przez ZSRR, z wyjątkiem jednak tych, które, jak wskazuje Konwencja wiedeńska z 1978 roku o sukcesji państw w odniesieniu do traktatów, dotyczą oderwanej części terytorium tego państwa $^{50}$. Biorąc pod uwagę fakt, że państwa powstałe na terytorium ZSRR zadeklarowały przejęcie całokształtu praw i obowiązków swojego poprzednika, są one kontynuatorami prawnomiędzynarodowej podmiotowości byłych republik związkowych ZSRR ${ }^{51}$. Należy więc uznać, iż ponoszą one również wynikającą stąd odpowiedzialność. Nie ponoszą one natomiast odpowiedzialności międzynarodowej za działanie lub zaniechanie pochodzące bezpośrednio od władz centralnych dawnego suwerena.

Odpowiedzialność międzynarodową za działania ZSRR ponosi Rosja jako jego kontynuator. W praktyce jednak odpowiedzialność ta nie zawsze jest realizowana. Ma to miejsce np. w odniesieniu do odpowiedzialności wynikającej z agresji, okupacji, aneksji oraz przebywania na terytorium państw bałtyckich wojsk ZSRR.

W wyniku rozpadu ZSRR podziałowi uległ majątek ZSRR znajdujący się na dotychczasowym jego terytorium oraz długi i aktywa zewnętrzne. $\mathrm{Na}$ spotkaniu szefów państw członkowskich Wspólnoty, które miało miejsce 6 VII 1992 r. w Moskwie, zostały przyjęte porozumienia dotyczące podziału pozostawionych po ZSRR własności, archiwów, długów i aktywów ${ }^{52}$.

Sukcesja państw członkowskich WNP w odniesieniu do terytorium była uregulowana według ogólnie uznanych zasad prawa międzynarodowego, a także na podstawie postanowień Konwencji Wiedeńskiej z 1978 r. Kwestia ta została uregulowana według zasady uti posidetis. Wobec tego granice terytoriów państw Wspólnoty pozostają takie, jakie zostały ustanowione w ramach byłego ZSRR. Nie oznacza to, że państwa nie roszczą żadnych pretensji odnośnie ustanowionych granic, żądania te jednak powinny być rozpatrywane i rozwiązywane w drodze porozumień, z uwzględnieniem interesów stron $^{53}$.

50 A. Przyborowska-Klimczak, Prawo międzynarodowe publiczne. Wybór dokumentów, Lublin 1998, s. 75.

51 Białoruś i Ukraina, bez składania jakichkolwiek dokumentów o kontynuację członkostwa w ONZ i w jej organizacjach wyspecjalizowanych, zostały za takie uznane.

52 Zob.: „Дипломатический Вестник”, op. cit., 1992, nr 15-16, s. 30 i n.

53 Przykładowo Rosja uważa za prawnie nieuzasadnione włączenie do Ukrainy Autonomicznej Republiki Krymu. Z kolei Estonia rości pretensje do części terytorium obwodów Leningradzkiego i Pskowskiego w Rosji. 
Kwestie dotyczące sukcesji państw członkowskich WNP w odniesieniu do mienia państwowego, archiwów i długów państwowych zostały uregulowane na podstawie Konwencji Wiedeńskiej z 1983 r. Zgodnie z art. 9 tego dokumentu własność państwowa, przechodzi bez odszkodowania na państwa-sukcesorów. Prawa poprzednika wygasają i w to miejsce powstają identyczne co do zakresu prawa sukcesora. Zmiana ta dokonuje się $\mathrm{w}$ dniu przekazania suwerenności ${ }^{54}$.

W podpisanym przez państwa członkowskie WNP porozumieniu o własności byłego ZSRR za granicą podkreślono, że państwa te uznają wzajemnie, że każde z nich ma prawo do odpowiednio ustalonej, sprawiedliwie wydzielonej części własności byłego ZSRR za granicą i będą sprzyjać realizacji tego prawa. Porozumienie w sprawie sukcesji po byłym ZSRR w odniesieniu do archiwów zostało podpisane między państwami członkowskimi Wspólnoty 6 lipca 1992 roku. Uznano w nim jako wiodącą zasadę integralności i niepodzielności archiwów, a także prawa do archiwów tych państw, na terytoriach których się znajdowały.

Majątek nieruchomy i ruchomy, znajdujący się na dotychczasowym terytorium ZSRR został podzielony również w oparciu o zasadę uti possidetis $\mathrm{w}$ drodze zawartych porozumień między państwami $\mathrm{WNP}^{55}$. Państwa członkowskie Wspólnoty podpisały także porozumienie o zwrocie dóbr kultury i dzieł sztuki państwom ich pochodzenia ${ }^{56}$.

54 W. Czapliński, Zmiany terytorialne w Europie Środkowej $i$ Wschodniej i ich skutki międzynarodowe (1990-1992), Warszawa 1998, s. 157.

55 Tabor kolejowy podzielony został na podstawie porozumienia z 22 stycznia 1993 r. zgodnie z ustalonym kluczem procentowym, natomiast samoloty Aeroflotu według miejsca ich rejestracji. Większość z nich przypadła Rosji. Wewnętrzny dług państwowy ZSRR stał się długiem państw, na terytorium których znajdowały się banki, do których dokonywano wpłat przez osoby fizyczne i prawne. Problem ten rozwiązano poprzez nacjonalizację tych środków i wypłacanie ich w ilości i na zasadach określonych przez dane państwo. Por.: Политико-правовые проблемы Содружества Независимых Государств, „Государство и Право”, Российская Академия Наук, 1993, nr 7, s. 101.

56 Porozumienie podpisano w Mińsku 14.02.92, tekst w: „Российская газета” z 24 lutego 1992 r. Umowa ta nie zostala zaakceptowana przez Radę Najwyższą RF i wobec tego nie mogła wejść w życie w stosunku do najważniejszego, z punktu widzenia realizacji jej celów, sygnatariusza. Ponowną próbę państwa członkowskie Wspólnoty podjęły w Taszkiencie 15 maja 1992 r. Porozumienie to przewidywało powołanie komisji, która miała opracować projekt umowy dotyczącej podziału zbiorów wywiezionych w czasie wojny z Niemiec do ZSRR, które zaproponowano traktować jako reparacje za dobra utracone w czasie wojny przez każde $\mathrm{z}$ zainteresowanych państw. Władze FR w odpowiedzi na przedstawiony projekt zaproponowały regulowanie pro- 
Kwestię zagranicznego długu i aktywów ZSRR uregulowano w drodze podpisania tzw. wariantu zerowego. Udział każdej strony w sumie ogólnego zewnętrznego zadłużenia ZSRR był określony według udziału każdej republiki związkowej w ówczesnym ogólnym eksporcie i imporcie oraz według wskaźnika posiadanej ludności. Wskaźnik ten był wykorzystany również przy określeniu części aktywów przysługujących każdemu z państw WNP po Związku Radzieckim ${ }^{57}$. Nie wszystkie byłe republiki związkowe były zgodne co do ustalonego ich udziału w długach i aktywach ZSRR. Umowę o przejęciu długów i aktywów ZSRR w odpowiednich udziałach podpisało 4 XII $1991 \mathrm{r}$. osiem republik związkowych ${ }^{58}$. Rosja i Ukraina 23 XI 1992 r. podpisały protokół, w którym Ukraina przekazała prawo do uregulowania długów i rozporządzania aktywami przysługującymi jej na czas określony w dokumencie, czyli do 31 XII 1992 r. Ukraina, zagłębiona w kryzysie ekonomicznym, podpisała jednak 11 XII 1994 roku z Rosją umowę o restrukturyzacji zadłużenia, tzn. przyjęła „opcję zerową”, tak jak uczyniły to pozostałe państwa członkowskie $\mathrm{WNP}^{59}$. „Wariant zerowy” polegał na przejęciu przez Rosję obowiązku spłaty zadłużenia ZSRR, w zamian za to Rosja stała się właścicielem całości zagranicznych wierzytelności i znajdującego się za granicą majątku ZSRR. Państwa bałtyckie odmówiły jakichkolwiek spłat części zadłużenia zagranicznego ZSRR. Z drugiej strony państwa te nie wyrzekły się mienia państwowego byłego ZSRR, znajdującego się na ich terytorium. Podjęły one także starania o zwrot byłej własności, a następnie przejętej przez ZSRR po aneksji w 1940 r.

W ramach Wspólnoty Niepodległych Państw zauważalne są dążenia integracyjne niektórych państw. Najściślejsze stosunki z FR utrzymuje Białoruśs ${ }^{60}$.

blemu repatriacji dziedzictwa kulturowego na podstawie umów dwustronnych między zainteresowanymi państwami. Zob. też J. Kukułka, Historia wspótczesna stosunków międzynarodowych 1945-1996, Warszawa 1996, s. 511.

57 Udział Rosji wynosi 61,34\%, Ukrainy 16,47\%, Białorusi 4,13\%, Kazachstanu 3,86\%, Uzbekistanu 3,27\%, Mołdowy 1,29\%, Kirgistanu 0,95\%, Armenii 0,86\%, Tadżykistanu 0,82\%, Turkmenistanu 0,70\%, Gruzji, Łotwy, Litwy, Estonii - ok. 4,77\%, „Вестник Московского Университета” 1993, nr 6, s. 54 i n.

${ }^{58}$ Umowa ta nie została podpisana przez Ukrainę, państwa bałtyckie, Azerbejdżan, Uzbekistan i Gruzję.

59 Zob.: „Генеза”, Студія Політологічного Центра, Київ 1995, nr 2, s. 5.

${ }^{60}$ Związek Rosji i Białorusi został zawarty z inicjatywy prezydenta Białorusi A. Łukaszenki 2 IV 1997 r. w celu osiągnięcia efektywnej integracji gospodarczej i społecznej. 
Jednak w 2006 r. między tymi państwami powstał konflikt dotyczący przede wszystkim sfery energetycznej (cen gazu eksportowanego na Białoruś oraz własności rurociagu gazowego „Biełtransgaz” wiodącego z Rosji do Europy przez Białoruś) ${ }^{61}$. Konflikt w sferze energetycznej nie rzutuje jednak na całokształt współpracy pomiędzy Rosją a Białorusią, która rozwija się najlepiej w porównaniu z innymi państwami Wspólnoty. Do zwolenników ściślejszej integracji w ramach WNP należą też Kazachstan i Kirgistan. Białorusi zależy głównie na uzyskaniu od Rosji znacznej pomocy gospodarczej i uprzywilejowanych stosunków handlowych. Kazachstan, współpracując z Rosją, kieruje się troską o swoją integralność terytorialną, stabilność ekonomiczną i suwerenność. Z kolei celem Kirgistanu jest utrzymanie dobrych stosunków politycznych i gospodarczych z Rosją oraz zachowanie wewnętrznej stabilności.

Obserwując szesnastoletnie funkcjonowanie Wspólnoty można wnioskować, że obecnie w jej ramach istnieją dwa obozy. Pierwszy z nich łączy Rosję, Białoruś, Kazachstan, Tadżykistan, Kirgistan oraz Armenię, jako obserwatora. W skład drugiej grupy wchodzą członkowie powstałej w 1997 roku GUAM (ГУАM) z siedzibą w Kijowie, której założycielami były Gruzja, Ukraina, Azerbejdżan i Mołdowa ${ }^{62}$. Państwa uczestniczące w tej organizacji podejmują konkurencyjne działania skierowane na stworzenie realnie efektywnej płaszczyzny integracyjnej w stosunku do samej Wspólnoty. Natomiast Turkmenistan nie jest zaangażowany w żaden z tych obozów. FR zajmuje niewątpliwie znaczącą pozycję wśród państw Wspólnoty, jednak nie udało się przełożyć jej pozycji na poważne wpływy na obszarach pozostałych państw. Ukraina i Mołdowa zmierzają stopniowo w kierunku Unii Europejskiej. Gruzja i Azerbejdżan zacieśniają współpracę ze Stanami Zjednoczonymi, przede wszystkim w zakresie bezpieczeństwa energetycznego. Natomiast Chiny umacniają swoje relacje z państwami Wspólnoty położonymi w Środkowej Azji ${ }^{63}$.

6118 października 2006 r. Rosja oficjalnie zapowiedziała ograniczenia w imporcie towarów z Białorusi. W odpowiedzi władze Białorusi podjęły rozmowy w sprawie importu surowców energetycznych z innymi państwami WNP. Zob. B. Wedrychowski, Publikacje Ośrodka Studiów Wschodnich, http://www.osw.waw.pl.

6224 kwietnia 1999 r. podczas szczytu NATO/EAPC w Waszyngtonie do GUAM przystąpiło kolejne państwo Uzbekistan, co spowodowało zmianę nazwy na GUUAM. Jednak 5 maja 2005 r. Uzbekistan zrezygnował z członkostwa w tej organizacji.

63 Por. V. Inozemtsev, Will CIS live to celebrate its $20^{\text {th }}$ anniversary?, RIA Novosti, http://www.rian.ru. 
Niejednokrotnie państwa takie jak Ukraina, Gruzja czy Mołdowa zgłaszały na szczytach państw WNP chęć wystąpienia ze Wspólnoty, jednak do tej pory tego nie uczyniły ${ }^{64}$. Powodem pozostania we Wspólnocie jest prawdopodobnie brak konkretnych propozycji dotyczących przystapienia do innych struktur międzynarodowych.

Obecny stan i rozwój WNP stawia wiele pytań i wątpliwości, a zarazem i możliwości. Z drugiej zaś strony istnieje duża współzależność tych państw, ukształtowana w toku długotrwałego procesu ich wspólnego rozwoju. Można więc stwierdzić, że WNP musi uczyć się budować jedność w różnorodności.

W interesie stabilności światowej nie leży, aby na przestrzeni postradzieckiej miały miejsce niekontrolowane procesy dezintegracyjne.

\section{Summary}

The agreement on the foundation of the Commonwealth of Independent States (CIS) and other documents signed by the members states to determine the scope of collaboration, their common objectives and principles, were an exclusive legal foundation of CIS until the CIS Statute was signed. The Statute does not determine the range of CIS's competence and it only stipulates the scope of joint operations of member states. CIS institutions, composed of high ranking officials from member states, only have coordinating competence. However, they are a forum for making common decisions concerning CIS functioning. CIS coordinating organs do not have the authority over member states either, and they can only make recommendations. The Commonwealth of Independent States is relatively young in comparison to other international structures. It is extremely difficult and usually time-consuming to create any form of integration, especially in the realm of politics. It is particularly complicated with respect to CIS as a coherent attitude of all, highly diversified, members is required to work out permanent principles of functioning.

${ }^{64}$ Zob. P. Goncharov, Is the CIS getting divorced?, ibidem. 